\title{
Krzysztof Paweł Woźniak
}

https://orcid.org/0000-0001-8238-4375

(Łódź)

\section{RELIGIJNY WYMIAR AKTYWNOŚCI SPOŁECZNEJ \\ W PROTESTANCKIM ŚRODOWISKU ŁÓDZKICH \\ PRZEMYSŁOWCÓW W XIX I XX W. NA PRZYKŁADZIE \\ RODZIN SCHEIBLERÓW, HERBSTÓW I GEYERÓW}

\section{Abstract}

The article outlines the outcomes of social activities undertaken by the elites of Protestant industrialists of Łódź in the 19th and 20th century, highlighting the religious motivations behind their initiatives. The author draws attention to the correlation between the Protestant worldview and ethics and the demands of the nascent capitalism, in the circumstances where the state failed to address the numerous social problems of the times.

\section{Key words}

Łódź, religion, Protestantism, industrial bourgeoisie, textile industry 
Dla ziem Polski środkowej, które po 1815 r. weszły w skład Królestwa Polskiego, doświadczanie skutków Reformacji zaczęło się późno, bo dopiero w latach 70. XVIII w. XVI-wieczny ruch reformacyjny nie pozostawił na tym obszarze żadnego trwałego śladu. Nie wykształciła się struktura zborowa (parafialna), nie przetrwały nigdzie najmniejsze bodaj społeczności protestanckie. Zmianę przyniosła dopiero trzecia tercja XVIII w., a spowodował ją napływ ludności chłopskiej wywodzącej się w niemieckiego kręgu kulturowego. Poczynając od zachodnich i północnych rubieży I Rzeczypospolitej, niemieckojęzyczni i protestanccy chłopi $\mathrm{w}$ kilku falach pojawili się na ziemiach polskich, w wielu przypadkach traktując je jedynie jako miejsce czasowego pobytu w drodze do Rosji, na stepy nadwołżańskie i do Besarabii ${ }^{1}$. Ta wywołana czynnikami ekonomicznymi migracja trwała z różnym nasileniem i w różnych formach organizacyjnych do lat 40 . XIX w. W jej efekcie na terenie Polski środkowej osiadła stosunkowo liczna społeczność protestancka, głównie luterańska, kultywująca do 1945 r. swą religijną i językową, a z czasem narodową, odrębność. W następstwie zmian zarówno politycznych, spowodowanych postanowieniami kongresu wiedeńskiego (1815), jak i gospodarczych, wywołanych z jednej strony zniesieniem blokady kontynentalnej (1814), a z drugiej powiązaniem Królestwa Polskiego z Rosją, rozpoczął się proces uprzemysławiania Królestwa. Jedną z jego charakterystycznych cech było osadnictwo przemysłowe, zainicjowane przez władze rządowe szeregiem aktów prawnych, zachęcających do osiedlania się w Królestwie „użytecznych rękodzielników" z krajów zachodnich, którzy nie mogąc sprostać konkurencji tańszych, maszynowo wytwarzanych wyrobów angielskich, pogrążyli się w kryzysie. Skutkiem tej kreacyjnej polityki władz Królestwa Polskiego było osiedlenie się na jego terenie, a zwłaszcza w osadach fabrycznych, kilkunastu tysięcy rzemieślników i manufakturzystów, głównie włókienników. Korzystne warunki rozwoju przemysłu tekstylnego sprawiły, że przybysze związali się z nową ojczyzną, znajdując w niej dogodne warunki życia i pracy. Duże znaczenie miały gwarancje poszanowania odrębności religijnych i kulturowych osadników przemysłowych, co pozwoliło im kultywować język i wiarę przodków$^{2}$. Wszystkie te okoliczności sprawiły, że w Łodzi, która z upływem lat wyrosła na metropolię przemysłu włókienniczego, społeczność protestancka stanowiła do lat 60. XIX w. ponad połowę ogółu mieszkańców miasta. Z czasem ten udział zmniejszał się, do ok. 21\% w 1914 r. i ok. 9\% w 1939 r. ${ }^{3}$

\footnotetext{
${ }^{1}$ Brandes 1993, Woźniak 2013.

${ }^{2}$ Gastpary 1977 , s. $244-271$.

${ }^{3}$ Janczak 1982, s. 108-109. Rzepkowski 2008, s. 117.
} 
Wypracowana przez pokolenia pozycja finansowa sprawiała, że we wszystkich dziedzinach życia grupa ta była najbardziej widoczna. Społeczność luterańska znajdowała mocne oparcie w strukturach swojego Kościoła, który dla żyjących $\mathrm{w}$ diasporze wiernych był także łącznikiem $\mathrm{z}$ tradycją i kulturą ich dawnej ojczyzny.

Mimo szerokiego rozpoznania obszarów aktywności i stylu życia burżuazji Królestwa Polskiego, w tym łódzkiej, w XIX i XX w. nasza wiedza o praktykach religijnych w tym środowisku jest znikoma ${ }^{4}$. Ogranicza się ona do znajomości zewnętrznych przejawów uczestnictwa w życiu parafii (wspólnoty wyznaniowej) ${ }^{5}$. Warto zauważyć, że znakomita praca Daniela Olszewskiego „Polska kultura religijna na przełomie XIX i XX wieku” w żadnym fragmencie nie odnosi się do kwestii praktyk religijnych protestantów. Dokumenty konsystorskie i synodalne mówią o całej zbiorowości protestanckiej Królestwa Polskiego i nie jest możliwe odniesienie zawartych w nich informacji wprost do opisywanego kręgu łódzkich luteranów. Wydawany przez Wilhelma Pawła Angersteina „Evangelisch-Lutherisches Kirchenblatt” (1884-1914) oraz jego polskojęzyczna wersja "Głosy Kościelne w Sprawie Kościoła Ewangelicko-Augsburskiego" (1884-1890), poprzestają na kronikarskim odnotowywaniu aktów ofiarności i zaangażowania społecznego parafian. Poza wspomnieniami Heleny Anny Geyer, żony zamożnego łódzkiego przedsiębiorcy, Gustawa Geyera, nie dysponujemy żadnym przekazem autobiograficznym, który ukazywałby miejsce religii w życiu elity łódzkich przedsiębiorców - protestantów ${ }^{6}$. Na nielicznych próbach opisu religijności elity łódzkich protestantów ciąży sposób postrzegania tego zjawiska wywiedziony wyłącznie z doktryny rzymskokatolickiej, w której pracy i jej owocom nadaje się inne znaczenie, niż w doktrynie protestanckiej. Do problematyki tej nie wnoszą też niczego publikacje najnowsze: Hanny Krajewskiej oraz zespołu historyków łódzkich - Kazimierza Badziaka, Karola Chylaka i Małgorzaty Łapy ${ }^{8}$.

Religijny kontekst aktywności społecznej łódzkich luteranów można odtworzyć, posiłkując się ułamkowymi i rozproszonymi przekazami źródłowymi, biorąc pod uwagę zarówno doktrynalne zasady luteranizmu, jak i życiowe osiągnięcia przedstawicieli tego środowiska. Z racji zarówno skali zrealizowanych przedsięwzięć, jak i chronologicznej ciągłości podejmowanych inicjatyw

\footnotetext{
${ }^{4}$ Woźniak 2012, s. 47-65.

${ }^{5}$ Kopczyńska-Jaworska i Woźniak 2002; Kopczyńska-Jaworska 1977, s. 115-127.

${ }^{6}$ Geyer 2002.

${ }^{7}$ Pytlas 1994, s. 366.

${ }^{8}$ Krajewska 2014. Badziak, Chylak i Łapa 2014.
} 
przedmiotem szczególnej uwagi mogą być dokonania przedstawicieli szeroko rozrodzonych rodzin: Geyerów oraz Scheiblerów-Herbstów.

W jednej ze współczesnych opinii o łódzkich dokonaniach Karola Wilhelma Scheiblera (1820-1881) stwierdza się, że: „także w swojej nowej ojczyźnie pozostał wierny protestanckiej religii (...) a swoim postępowaniem dał dowód pobożności"9. Zachęca to do dociekań i poszukiwania owego dowodu, zwłaszcza tam, gdzie aktywność interesującego nas kręgu osób była najżywsza, czyli na polu inicjatyw gospodarczych i społecznych.

Twórca najpotężniejszego w dziejach Łodzi przedsiębiorstwa włókienniczego miał wśród swoich przodków co najmniej kilku pastorów luterańskich $^{10}$. Pamięć o antenatach $\mathrm{w}$ kaznodziejskich togach nie była jednak kultywowana w następnych pokoleniach. Wzorem swego ojca, Karol Wilhelm Scheibler wybrał profesję włókienniczą, osiągając w niej szczyty powodzenia ${ }^{11}$. Także żaden $\mathrm{z}$ jego potomków nie wybrał kariery duchownego. Kontynuowali dzieło ojca, a Karol Wilhelm jr okazał się godnym spadkobiercą myśli i majątku ojca.

Marcin Luter wielokrotnie podkreślał, że chrześcijanin nie przynależy wyłącznie do rzeczywistości sakralnej, lecz także do świeckiej, dlatego powinien przyjąć na siebie odpowiedzialność za oba porządki: zbawienia i świeckiego bytowania. Tym samym można przyjąć, że dokonania życiowe członków wspólnoty protestanckiej były motywowane swoistymi poglądami teologicznymi i etycznymi ${ }^{12}$. Max Weber trafnie zauważył, że pomiędzy porządkiem społecznym a religią istnieje wzajemna zależność. Stąd też nie tylko religia kształtowana jest przez system społeczny, lecz również ten system jest uwarunkowany strukturą religii, co oznacza, że religia może przyspieszać lub hamować pewne procesy społeczne ${ }^{13}$. Podobnie, za M. Weberem, uważa się, że luteranizm jedynie zapoczątkował zwrot ku racjonalności i ascezie. Metodycznie zostały one wcielone w życie przez kalwinizm, a w jeszcze większym stopniu przez purytanizm ${ }^{14}$. Teologia protestancka nie zna pojęcia pracy jako kary za grzech pierworodny. Bóg uświęca pracę ludzką, czyniąc ją powołaniem człowieka na świecie. Dlatego solidne, rzetelne wykonywania zawodu urosło $\mathrm{w}$ protestantyzmie do rangi pożądanej cnoty, zyskało legitymację

\footnotetext{
${ }^{9}$ Kornacker 1998, s. 126.

${ }^{10}$ Schedler 1929, s. 24, Kornacker 1998, s. 121.

${ }^{11}$ Pustuła 1994, s. 426-428, Pytlas 1998a, s. 18, Puś i Pytlas 1979, s. 32.

${ }^{12}$ Milerski 1998, s. 231-232.

${ }^{13}$ Ibidem, s. 233.

${ }^{14}$ Weber 1994, s. 115, Koffler 1979, s. 158-168.
} 
religijną. Przesłanki te prowadziły do powstania kulturowej korelacji między etosem protestanckim a duchem kapitalizmu, co jednoznacznie wyraził w XVIII w. prekursor metodyzmu, Jan Wesley ${ }^{15}$. Pomnażanie bogactwa nie jest zatem $\mathrm{w}$ protestantyzmie grzechem. Wręcz przeciwnie: gromadzenie dóbr nie do konsumpcji, lecz w celu odpowiedniego dalszego wykorzystania jest cnotą o wielkiej wartości, podobnie jak wstrzemięźliwy tryb życia, surowość obyczajów, uświęcenie pracy - zwłaszcza manualnej, traktowanej jako powołanie od Boga. We współczesnej homiletyce Kościoła ewangelicko-augsburskiego akcentuje się (bp Jan Cieślar) pojęcia etosu odpowiedzialności, spolegliwości, jako cechy charakteryzujące pobożność protestancką. $\mathrm{Na}$ gruncie łódzkim potwierdziła się współzależność światopoglądu i etyki protestanckiej z wymaganiami rodzącego się kapitalizmu ${ }^{16}$. Osiedlający się w mieście od lat 20. XIX w. protestanccy przybysze przynieśli ze sobą znaczny kapitał umiejętności, znajomość sposobów prowadzenia przedsiębiorstwa przemysłowego, przyzwyczajenie do wytężonej pracy. Fachowość mająca swoje źródło w praktyce zawodowej, połączona z rzutkością i przedsiębiorczością, pozwoliła najzdolniejszym $\mathrm{z}$ nich zrobić błyskawiczne kariery. O sukcesie zawodowym i życiowym decydował splot umiejętności i wykorzystanych okoliczności. Nierzadko powodzenie zależało od gotowości do podjęcia ryzyka ${ }^{17}$.

Podstawowe zasady religijne luteranizmu, a szerzej protestantyzmu (tylko wiara, tylko łaska, tylko Pismo, tylko Chrystus), promowały autonomię człowieka, uwalniając zarazem jego sumienie, które nie podlegało już osądowi ludzkiemu, lecz przede wszystkim boskiemu. Skłaniało to do prowadzenia niezależnych i nieskrępowanych poszukiwań religijnych, często na obrzeżach ortodoksji. Sola scriptura - tylko Pismo, naczelna zasada protestantyzmu, oznacza, że Pismo Święte jest dla chrześcijanina samowystarczalnym źródłem wiary a w konsekwencji jedynym autorytetem Kościoła w sprawach wiary i praktyki. Wyznania protestanckie kładą duży nacisk na indywidualność przeżycia religijnego, nie narzucając np. obowiązku uczestnictwa w nabożeństwach, lecz dozwalają, czy wręcz zalecają każdemu wiernemu stały kontakt ze Słowem Bożym przez czytanie Pisma Świętego ${ }^{18}$. Stąd tradycja czytania Biblii, która znajdowała się $\mathrm{w}$ każdym ewangelickim domu. W ten sposób życie codzienne nasycane było elementem sacrum. Z badań etnograficznych

\footnotetext{
${ }^{15}$ Milerski 1998, s. 239.

${ }^{16}$ Weber 1984, s. 88-110, Markiewicz 1982, s. 112-113.

${ }^{17}$ Woźniak 1998, s. 97-98.

${ }^{18}$ Zuberbier i in. 1988, s. 21.
} 
wiadomo, że w łódzkim środowisku ewangelickim zwyczaj domowego czytania Pisma Świętego i wspólnej modlitwy przed posiłkiem praktykowany był niemal powszechnie do czasu II wojny światowej ${ }^{19}$. Wskazuje to jednocześnie na znaczącą rolę rodziny w kształtowaniu życia duchowego wspólnoty ewangelickiej.

Ewangelicka kultura życia codziennego w obszarze sakralnym i świeckim opiera się na dwóch podstawowych wartościach: autonomii i wolności sumienia ${ }^{20}$. Autonomia widoczna jest choćby w samej strukturze organizacyjnej Kościoła ewangelicko-augsburskiego, w którym wierni posiadają szeroki zakres wypowiadania się w sprawach parafii, dysponując m. in. prawem wyboru pastora. Zgromadzenia Parafialne, a zwłaszcza Kolegia Kościelne, były zawsze organami współdecydującymi w kwestiach najżywotniejszych dla parafian. Dzieje łódzkiej społeczności protestanckiej przekonują, że autonomia i wolność sumienia $\mathrm{w}$ obszarze religijnym zostały rozciągnięte na aktywność wyznawców w obszarze świeckim, co przyczyniło się znacząco do rozwoju gospodarczego i kulturalnego miasta ${ }^{21}$. Uczestnictwo w Kolegiach Kościelnych, komitetach budowy kościołów, liczne datki na różne cele społeczne, a przede wszystkim zaangażowanie w szeroko rozumianą dobroczynność i filantropię, dają odpowiedź na pytanie, jak dalece protestanci łódzcy byli religijni, jakie zasady swego wyznania wcielali w życie. Trzeba bowiem pamiętać, że w protestantyzmie, zupełnie inaczej niż w religii rzymskokatolickiej, dobre uczynki człowieka nie mają znaczenia teologicznego. Czynienie dobra jest czymś oczywistym i nie ma żadnego wpływu na zbawienie, które jest wyłącznie łaską Boga. Ta zasada dobitnie uwypukla znaczenie i religijny wymiar dobroczynności. Uwarunkowania polityczne w Królestwie Polskim po $1864 \mathrm{r}$. sprawiły, że wysiłki podejmowane w zakresie szeroko rozumianej filantropii i dobroczynności nie ograniczały się do indywidualnych i okazjonalnych aktów hojności i miłosierdzia, lecz przyjęły formy instytucjonalne, trwałe. Wydaje się, że w dotychczasowych studiach nad dziejami środowiska przemysłowców łódzkich nie dostrzegano komponentu religijnego w społecznym zaangażowaniu jego przedstawicieli. Dostrzegając inne czynniki (chęć autoreklamy, zapobieganie „niepokojom społecznym”), widziano w tej aktywności „postawę spolegliwą, wynikającą z szeroko pojętego humanitaryzmu, z pełnego zrozumienia i współczucia dla ludzi doświadczonych przez los”22.

\footnotetext{
${ }^{19}$ Kopczyńska-Jaworska 1977, s. 115-127, Kopczyńska-Jaworska 1999, s. 131.

${ }^{20}$ Milerski 1998, s. 234.

${ }^{21}$ Ibidem, s. 237.

${ }^{22}$ Pytlas 1994, s. 168.
} 
Szeroka gama różnych form aktywności społecznej, prezentowanej przez najzamożniejsze kręgi łódzkiej społeczności protestanckiej, znacznie bogatsza od analogicznych przedsięwzięć podejmowanych w środowisku katolickim czy żydowskim, każe poszukiwać w nich inspiracji religijnych.

Początki działalności filantropijnej w Łodzi łączą się z łagodzeniem skutków pierwszego w historii miasta kryzysu gospodarczego lat 1845-1847. W zawiązanym wówczas Komitecie Opieki i Wsparcia Ubogich czołową rolę odgrywał jeden z inicjatorów jego utworzenia, Ludwik Geyer (1805-1869). Właściciel pierwszej maszyny parowej w przemyśle łódzkim, już za życia nazwany „królem bawełny”, angażował się w liczne inicjatywy (kwesty, gromadzenie żywności i opału celem rozdawnictwa ubogiej ludności) i przedsięwzięcia służące ogółowi mieszkańców. Podobnie postąpił podczas kryzysu, tzw. głodu bawełnianego w $1861 \mathrm{r}^{23}$ Przez szereg lat L. Geyer pełnił funkcję członka Rady Opiekuńczej pierwszego szpitala miejskiego. Na znacznie szerszą skalę włączą się w działalność charytatywną i dobroczynną synowie Ludwika wraz ze swymi rodzinami. Stanie się to po wydźwignięciu rodzinnej firmy z zapaści, którą przeszła w latach 70. XIX w.

Prześledzenie etapów rozwoju przedsiębiorstwa scheiblerowskiego i zaangażowania jego właściciela $\mathrm{w}$ obszarze pozazawodowym pozwala dostrzec wymowną korelację. Gdy przedsiębiorstwo okrzepło, jego właściciel zaczął realizować motywowaną religijnie zasadę dobrego spożytkowania zgromadzonego majątku. W ciągu 27 lat pobytu w Łodzi Karol Wilhelm Scheibler stworzył olbrzymi kombinat włókienniczy $\mathrm{z}$ towarzyszącą mu infrastrukturą miejską i stał się jednym z najzamożniejszych bourgeois w Królestwie Polskim, ustępując zamożnością jedynie warszawskiemu bankierowi, Leopoldowi Kronenbergowi ${ }^{24}$. Liczący kilkanaście milionów rubli majątek przeszedł w ręce wdowy, Anny z Wernerów (1835-1921), która przeżyła męża o lat 40 i umiejętnie, wraz z członkami rodziny, zarazem udziałowcami firmy, zarządzała przedsiębiorstwem. Szczególnie eksponowaną rolę pełnił w nim zięć, Edward Herbst (1844-1921), dyrektor generalny spółki.

Pierwszym śladem religijnego zaangażowania Karola Wilhelma Scheiblera jest ufundowany przez niego obraz do ołtarza głównego w kościele ewangelickim w Łęczycy. Miało to miejsce między 1848 a 1854 r., kiedy Scheibler pełnił funkcję dyrektora przędzalni bawełny w Ozorkowie. Wcześnie, bo już w dziesięć lat po rozpoczęciu działalności przemysłowej w Łodzi, stanął

\footnotetext{
${ }^{23}$ Rynkowska 1948-1958, s. 414-415, Rynkowska 1975, s. 61-98.

${ }^{24}$ Rynkowska 1975, s. 82.
} 
K.W. Scheibler na czele Kolegium Kościelnego parafii św. Trójcy i przez dwie kadencje (1864-1872) pełnił funkcję prezesa ${ }^{25}$. Ten wybór świadczył o docenieniu pozycji, jaką przedsiębiorca musiał już wówczas zajmować w społeczności ewangelickiej. Jedyna wówczas w Łodzi parafia ewangelicko-augsburska skupiała ponad 17 tys. wiernych i była najliczniejszą w Królestwie Polskim. Prezesura Scheiblera przypadła na najtrudniejszy chyba okres w jej dziejach. $\mathrm{Na}$ niepokój i niestabilność sytuacji politycznej wywołanej powstaniem styczniowym nałożyły się konsekwencje usunięcia przez władze rosyjskie w 1865 r. pastora Karola Gustawa Manitiusa, oskarżanego o sprzyjanie powstańcom ${ }^{26}$. Od 1876 r. K.W. Scheibler przewodniczył Komitetowi Budowlanemu powołanemu w celu wzniesienia drugiej świątyni luterańskiej w Łodzi. Funkcję tę pełnił aż do śmierci, ofiarowując na tę inwestycję 50 tys. rubli ${ }^{27}$. Ten hojny dar przesądził o wydaniu przez administrację carską zgody na rozpoczęcie budowy ${ }^{28}$. Po poświęceniu świątyni w 1884 r. Edward Herbst ufundował jej ogrodzenie, a Anna Scheibler przeznaczyła 10 tys. rb na budowę szkółki parafialnej. Dodatkowo cała rodzina Scheiblerów i Herbstów ofiarowała 30 tys. rb na plebanię zbudowaną w latach $1885-1886^{29}$. Dzięki ofiarności obu rodzin kościół otrzymał organy, wielki żyrandol i drobne sprzęty do wyposażenia wnętrza ${ }^{30}$. Należy podkreślić, że w wyposażaniu kościoła w sprzęty i paramenty liturgiczne uczestniczyli także inni łódzcy przedsiębiorcy luteranie. Tradycją było obdarowywania kościoła z okazji uroczystości rodzinnych, zwłaszcza ślubów ${ }^{31}$. W życie nowej łódzkiej parafii luterańskiej aktywnie zaangażował się Edward Herbst, zasiadając w latach 1884-1914 w Kolegium Kościelnym ${ }^{32}$.

Scheiblerowie i Herbstowie przyczynili się w ogromnej mierze do budowy i wyposażenia kilku łódzkich świątyń chrześcijańskich. W literaturze akcentuje się zaangażowanie obu rodzin w budowę łódzkich cerkwi prawosławnych, widząc w tej aktywności jedynie przejaw lojalizmu wobec władz carskich. Nie ulega wątpliwości, że wznoszenie cerkwi było traktowane przez administrację rosyjską jako symboliczne potwierdzenie podporządkowania

\footnotetext{
${ }^{25}$ Schedler 1929, s. 89.

${ }^{26}$ Schmidt b.r.w., s. 24, Czembor 1998, s. 51.

${ }^{27}$ Dziennik Łódzki 1884, nr 225, s. 4, Pytlas 1994, s. 364, Stefański 1995, s. 45.

${ }^{28}$ Strzałkowski 2005, s. 18.

${ }^{29}$ Jubiläumsschrift 1913, s. 74, Dietrich 1934, s. 34.

${ }^{30}$ Angerstein 1909, s. 7.

${ }^{31}$ Tamże, s. 9.

32 Pytlas 1994, s. 366.
} 
Przywiślańskiego Kraju ${ }^{33}$. Prawdą jest także, że łódzka, nieliczna jeszcze, społeczność prawosławna nie potrzebowała aż tak dużego obiektu, jakim była cerkiew pw. św. Aleksandra Newskiego. Nie była też w stanie sfinansować tej inwestycji. Dlatego odwołano się do hojności zamożnych przedsiębiorców protestanckich i żydowskich ${ }^{34}$. Na czele Komitetu Budowlanego cerkwi stanął Karol Scheibler, który wspólnie z żoną ofiarował kwotę 24650 rb, najwyższą spośród wszystkich darczyńców. Z kolei Edward Herbst przekazał 9 tys. rb w gotówce oraz różne sprzęty cerkiewne ${ }^{35}$. Kilka lat później tenże E. Herbst i K.W. Scheibler jr (1862-1935) ofiarowali po $500 \mathrm{rb}$ na rzecz „wykończenia i robót budowlanych przy cerkwi prawosławnej" w gubernialnym Piotrkowie $^{36}$. Kiedy w 1896 r. administracja carska zdecydowała się wznieść cerkiew garnizonową dla stacjonującego $\mathrm{w}$ Łodzi pułku piechoty, łódzcy przedsiębiorcy pospieszyli z pomocą finansową. Wśród ofiarodawców i członków Komitetu Budowlanego nie zabrakło E. Herbsta i K.W. Scheiblera jr. Otwartość na potrzeby społeczności innych niż „własna”, luterańska, widać także choćby w zaangażowaniu się K.W. Scheiblera w sprawę budowy synagogi dla Żydów reformowanych, i to jeszcze przed rozpoczęciem inwestycji. Na rok przed śmiercią, K.W. Scheibler ofiarował zapisem na rzecz synagogi kwotę 15 tys. $\mathrm{rb}^{37}$.

Podobnie, jako przejaw otwartości i poszanowania dla innych wyznań, traktować trzeba pokaźne sumy łożone przez rodziny Scheiblerów i Herbstów na budowę i wyposażenie łódzkich kościołów katolickich. W postawie tej można też upatrywać przejaw większej niż w innych środowiskach tolerancji wyznaniowej, cechującej protestantów ${ }^{38}$. Na rozpoczętą w 1860 r. i paraliżowaną przez lata trudnościami finansowymi budowę kościoła pw. Podwyższenia Krzyża Świętego, drugiej świątyni katolickiej w Łodzi, K.W. Scheibler dał 50 tys. rb. Jego darem były też sprowadzone $\mathrm{z}$ Berlina-Charlottenburga 4 figury ewangelistów zdobiące wieżę oraz zainstalowane w kościele 31-głosowe organy. W tej samej świątyni, w pierwszą rocznicę śmierci K.W. Scheiblera, jego zięć E. Herbst ufundował za 1900 rb ołtarz ku czci św. Jana Nepomucena. Kilka lat później Herbstowie sfinansowali budowę krużganków i prac malarskich wykonanych we wnętrzu kościoła ${ }^{39}$. W latach 1887-1892 Scheiblerowie

\footnotetext{
${ }^{33}$ Ibidem, Stefański 2016, s. 53-54.

${ }^{34}$ Wiernicka 2015 , s. 52-53.

${ }^{35}$ Rozwój 1901, nr 69, s. 6.

${ }^{36}$ Dziennik Łódzki 1884, 182, s. 5.

${ }^{37}$ Dziennik Łódzki 1887, 210, s. 6.

${ }^{38}$ Czembor 1998, s. 133-150.

${ }^{39}$ Dziennik Łódzki 1886, 3, s. 5.
} 
ofiarowali łącznie 50 tys. rb na budowę kolejnego kościoła katolickiego pw. Wniebowzięcia Najświętszej Marii Panny. Rodzina Scheiblerów-Herbstów znalazła się w latach 1898-1901 w grupie inicjatorów budowy kolejnego kościoła katolickiego (obecnie katedralnego) pw. św. Stanisława Kostki. Edward Herbst i Karol Wilhelm Scheibler jr zasiadali w komitecie budowlanym i należeli do czołowych fundatorów świątyni ${ }^{40}$. Obie rodziny ofiarowały na tę inwestycję 20 tys. rb, a w pierwszych latach XX w. małżonkowie Herbst ufundowali dodatkowo budowę chóru muzycznego. Znalazła się na nim istniejąca do dziś inskrypcja: „Miłość rodziców dla córki Anny Maryi Herbst wzniosła ten chór" ${ }^{\prime 1}$. W ten sposób fundatorzy pragnęli uczcić pamięć swej jedynej, przedwcześnie zmarłej córki Anny Marii Charitas (1889-1899). Ta sama myśl przyświecała zaangażowaniu się małżonków M. i E. Herbstów w budowę kościoła katolickiego pw. św. Anny. Na realizowaną w latach 1904-1906 inwestycję ofiarowali 20 tys. $\mathrm{rb}^{42}$. Darczyńcy pokryli też koszty odlania dzwonów, wykonania zegara wieżowego i mozaikowej posadzki ${ }^{43}$. Kiedy na początku XX w. łódzka społeczność protestancka podjęła budowę kolejnego kościoła luterańskiego pw. św. Mateusza, rodzina Geyerów podarowała parafii parcelę po jego budowę, a Anna Scheibler przeznaczyła na inwestycję 40 tys. rb.

O otwartości łódzkiego Kościoła ewangelicko-augsburskiego przekonuje m. in. skala konwersji na luteranizm. W parafii św. Jana w latach 1884-1940 zarejestrowano ponad 500 przypadków zmiany wyznania $\mathrm{z}$ wszystkich niemal denominacji chrześcijańskich oraz z judaizmu. Przewodzący tej parafii przez blisko pół wieku ks. W.P. Angerstein, uchodzący za zwolennika ortodoksyjnego luteranizmu, wyraził opinię, że „gdy Żyd z przekonania staje się chrześcijaninem, staje się gorliwym wyznawcą i chlubą Kościoła" ${ }^{4}$.

Res sacra miser - nieszczęśliwy jest rzeczą świętą, to maksyma, która patronowała bardzo szeroko zakrojonej działalności dobroczynnej rodziny Scheiblerów i Herbstów. Wielkoprzemysłowa Łódź pozbawiona była jakiejkolwiek polityki społecznej ze strony administracji rosyjskiej. Ogrom potrzeb w zakresie zdrowotności, oświaty, opieki społecznej wymagał zarówno niebagatelnych nakładów finansowych, jak i ukształtowania środowiska społeczników, którzy gotowi byliby ponieść trud łagodzenia negatywnych zjawisk.

${ }^{40}$ Pytlas 1994, s. 364.

${ }^{41}$ Stefański 1995, s. 49.

${ }^{42}$ Jubiläumsschrift 1913, s. 81.

${ }^{43}$ Walaszczyk 2006, s. 27.

${ }^{44}$ Głosy Kościelne w Sprawie Kościoła Ewangelicko-Augsburskiego 1885, 15, s. 9. 
Niezbędne było zorganizowanie szeregu wyspecjalizowanych instytucji, które stworzyły system łagodzący skutki najbardziej odczuwalnych zaniedbań. Najhojniejszym darczyńcą na rzecz budowanego od 1880 r. przytułku dla biednych, starców i osób kalekich był K.W. Scheibler, który ofiarował ponad połowę potrzebnych środków ${ }^{45}$. Dalsze 2 tys. rb na urządzenie trzech „tanich kuchni” pochodziło z kasy jego przedsiębiorstwa ${ }^{46}$. Kiedy w 1887 r. przy parafii ewangelickiej św. Trójcy powstał dom sierot, w jego zarządzie znaleźli się wszyscy najwięksi łódzcy potentaci luteranie z Anną Scheibler, Karolem Wilhelmem Scheiblerem jr., małżonkami M. i E. Herbstami oraz Heleną Anną Geyer ${ }^{47}$. Kiedy w 1899 r. z inicjatywy przemysłowca Emila Geyera założone zostało Towarzystwa Doraźnej Pomocy Lekarskiej, to w pierwszym jego zarządzie zasiadł K.W. Scheibler jr, a Anna Scheibler znalazła się w gronie członków protektorów ${ }^{48}$. Wszyscy wymienieni oraz Edward Herbst zadeklarowali roczną składkę $\mathrm{w}$ wysokości po 1 tys. rb na rzecz pogotowia. Za ich przykładem poszli inni przedsiębiorcy ${ }^{49}$. Swoistym ukoronowaniem przedsięwzięć realizowanych przez łódzkich przedsiębiorców na polu dobroczynności była budowa w 1897 r. okazałego gmachu, mieszczącego przytułek dla starców i kalek. Największą kwotę na ten cel, 50 tys. rb, ofiarowali Scheiblerowie ${ }^{50}$.

Inwestycją, która połączyła wysiłki najzamożniejszych łódzkich przedsiębiorców protestanckich, była budowa szpitala pediatrycznego. Inicjatorami jego utworzenia byli już w pierwszych latach XX w. bracia Emil i Eugeniusz Geyerowie, którzy do 1914 r. przeznaczyli na jego rzecz 45 tys. $\mathrm{rb}^{51}$. Z kolei Matylda i Edward Herbstowie stali się głównymi fundatorami (kwotą 200 tys. rb) dalszego wyposażania i utrzymania szpitala, upamiętniając także w jego nazwie swą zmarłą 10-letnią córkę Annę Marię Charitas. Otwarta w 1905 r. placówka była wzorcowym szpitalem pediatrycznym w skali trzech zaborów ${ }^{52}$. W 1908 r. Herbstowie zorganizowali w nim kosztem 12 tys. rb gabinet ortopedyczny. Szpitalem kierował zarząd, z E. Herbstem jako prezesem. Matylda Herbst była kuratorką a Anna Scheibler protektorką szpitala ${ }^{53}$. W jego

${ }^{45}$ Dziennik Łódzki 1885, 64, s. 5.

${ }^{46}$ Pytlas 1998a, s. 120.

${ }^{47}$ Supady 1997, s. 281.

${ }^{48}$ Księga pamiątkowa 1927, s. 8-9, Pytlas 1998a, s. 125.

${ }^{49}$ Pytlas 1994, s. 180.

${ }^{50}$ Pytlas 1998a, s. 129.

${ }^{51}$ Supady 1979, s. 19.

${ }^{52}$ Ibidem.

${ }^{53}$ Krajewska 1999, s. 182-183. 
utrzymaniu, w poważnym stopniu partycypowali także Geyerowie. W $1910 \mathrm{r}$. przekazano szpital pod zarząd Łódzkiego Chrześcijańskiego Towarzystwa Dobroczynności. Herbstowie ofiarowali wówczas kwotę 100 tys. rb jako tzw. kapitał żelazny i 50 tys. rb na bieżące potrzeby, co gwarantowało stabilność finansową placówki ${ }^{54}$.

$\mathrm{Z}$ powodzeniem realizowano też budowę szpitala dla nerwowo i psychicznie chorych „Kochanówka”, zlokalizowanego na zachodnich przedmieściach Łodzi. Szczególnie mocno w jego organizację zaangażowała się rodzina Geyerów ${ }^{55}$. „Moralnym twórcą” tej instytucji, przewodniczącym komitetu budowlanego, był dr Karol Jonscher, spowinowacony z rodziną Geyerów, przez szereg lat ich lekarz rodzinny ${ }^{56}$. Do wybuchu I wojny światowej wzniesiono, głównie dzięki nakładom Emila, Egeniusza i Ryszarda Geyerów, pięć pawilonów szpitalnych, w których można było pomieścić 300 chorych. Zabudowania uległy poważnym zniszczeniom $\mathrm{w}$ trakcie działań wojennych jesienią 1914 r. Odbudowę zakończono dopiero pod koniec 1916 r. Oba wspomniane szpitale czynne są do dziś, spełniając swoje pierwotne funkcje.

$\mathrm{Z}$ nie mniejszym zaangażowaniem niż w sprawy szpitalnictwa, łódzcy zamożni protestanci animowali przedsięwzięcia $z$ zakresu także zaniedbanej opieki społecznej. Najwcześniej przystąpiono do organizowania opieki nad matką i dzieckiem. Kiedy u schyłku lat 80. XIX w. środowisko lekarskie wysunęło projekt założenie Izby Porodowej, zyskał on natychmiastowe poparcie Anny i Olgi Geyer, które przeznaczyły na ten cel 1,5 tys. rb, apelując jednocześnie do sfer przemysłowych o ofiarność. W efekcie, otwarta w 1891 r. Izba Porodowa, dysponowała środkami w wysokości 10,3 tys. rb, co pozwalało na stabilną działalność. Placówką tą kierował komitet, w którym zasiadali m.in. Ryszard i Eugeniusz Geyerowie oraz Karol Wilhelm Scheibler jr. W latach 1904-1913 przewodniczyła komitetowi Jadwiga Geyer, a w jego zarządzie pracowała Helena Anna Geyer ${ }^{57}$. Wydarzenia rewolucji 1905-1907 r. spowodowały gwałtowne i znaczące pogorszenie sytuacji materialnej środowiska robotniczego. W 1907 r. zorganizowane zostało „Łódzkie Gniazdo” Warszawskiego Towarzystwa Opieki nad Bezdomnymi Dziećmi i Dziećmi z Rodzin Dotkniętych Lokautem. Jego działalność finansowana była przez Geyerów: Egeniusza, Emila, Wandę z Geyerów Gettlichową, a przede wszystkim przez Helenę Annę Geyer, przewodniczącą zarządu. W 1910 r. podjęto

\footnotetext{
${ }^{54}$ Mogilnicki 1930, s. 11.

${ }^{55}$ Pytlas 1998b, s. 10-14.

${ }^{56}$ Geyer 2002, s. 25, 42.

${ }^{57}$ Sprawozdanie 1913, s. 17, 41.
} 
decyzję o budowie własnego domu „Gniazdo Łódzkie”. Na parceli zakupionej przez Geyerów wzniesiono nowoczesny, dobrze wyposażony budynek, w którym zapewniono miejsce pobytu i opiekę 80-90 sierotom. Obiekt, poważnie zniszczony podczas działań wojennych jesienią 1914 r., został odbudowany w $1926 \mathrm{r}^{58}$

W światopoglądzie protestanckim wysoką rangę nadaje się wiedzy i nauce. Już sam nakaz ciągłego obcowania z Pismem Świętym jest wyraźną wskazówką do pogłębiania wiedzy, dociekliwości, rozwoju intelektualnego. Stanowić to musiało wystarczającą przesłankę, by w środowisku łódzkich protestantów realizować inicjatywy niwelujące niedostatek instytucji oświatowych. Wielu światłych i zamożnych przedsiębiorców przyczyniło się swymi subwencjami do rozwoju szkolnictwa średniego, ogólnego i zawodowego. Skalą zaangażowanych środków i uzyskanych efektów, wyróżnił się K.W. Scheibler. Zbudowana w latach 1876-1877 trzyoddziałowa szkoła fabryczna, rozbudowana została w $1884 \mathrm{r}$. przez syna fundatora stała się najlepszą z tego typu szkół w mieście ${ }^{59}$.

Dynamicznie rozwijająca się u schyłku XIX w. Łódź boleśnie odczuwała brak szkół średnich o profilu ogólnym, które uzupełniałyby istniejącą od 1869 r. Wyższą Szkołę Rzemieślniczą, kształcącą skromną kadrę dla przemysłu włókienniczego. Wieloletnie starania o powołanie rządowego gimnazjum męskiego zakończyły się sukcesem dopiero w $1891 \mathrm{r}$. Mając nadzieję na uruchomienie szkoły, K.W. Scheibler zapisał przed śmiercią na jej rzecz kwotę 60 tys. rb, którą spadkobiercy podwyższyli w chwili rozpoczęcia inwestycji do 100 tys. rb. W efekcie w latach 1888-1891 powstał okazały budynek spełniający wszystkie wymogi stawiane wówczas obiektom szkolnym i stanowiący jeden $z$ bardziej interesujących gmachów publicznych. Scheibler ufundował też coroczne stypendia dla pięciu uczniów, przeznaczając na ten cel kwotę 10 tys. rb w formie depozytu bankowego ${ }^{60}$. Wspieranie szkolnictwa stało się tradycją rodzinną. W 1903 r. K.W. Scheibler jr przekazał 10 tys. rb na potrzeby wznoszonej wówczas Szkoły Rękodzielniczo-Przemysłowej, która była wówczas największym i najnowocześniejszym gmachem szkolnym w Łodzi a jej ściśle techniczny profil pozwolił kształcić kadry dozoru technicznego w przemyśle nie tylko łódzkim.

Początek XX stulecia przyniósł także kolejne inwestycje Scheiblerów w dziedzinie oświaty i wychowania dzieci. W latach 1912-1913 Anna

\footnotetext{
${ }^{58}$ Sosnowska 2017, s. $262-275$.

${ }^{59}$ Stefański 2016, s. 60-61.

${ }^{60}$ Pamiatnaja Kniżka 1888, s. 72-73.
} 
Scheibler sfinalizowala budowę przyfabrycznej ochronki, czyli instytucji, która łącząc funkcje dzisiejszych żłobka i przedszkola, zapewniały opiekę nad dziećmi robotników kombinatu scheiblerowskiego. Do ochronki uczęszczało 250 dzieci w wieku od 4 do 6 lat $^{61}$. W bezpośrednim sąsiedztwie i w tym samym czasie rozpoczęto budowę gmachu kolejnej szkoły przyfabrycznej, finansowaną także przez Annę Scheibler. Placówka została uruchomiona we wrześniu 1914 r., mimo trwającej już wojny.

Najbardziej widocznym symbolem łączenia wskazanych przez Marcina Lutra dwóch porządków: świeckiego i sakralnego, jest kaplica nagrobna wzniesiona w 1888 r. dla Karola Wilhelma Scheiblera przez Annę Scheibler na Starym Cmentarzu w Łodzi. Kosztem 220 tys. rb powstała budowla uchodząca dzisiaj za jeden z najpiękniejszych w Europie neogotyckich zabytków sztuki sepulkralnej. Wzniesiona na planie krzyża łacińskiego, dwukondygnacyjna, z wysoką ażurową wieżą, łączy w sobie najlepsze cechy gotyku francuskiego i niemieckiego ${ }^{62}$. W podziemnej krypcie obok K.W. Scheiblera spoczęli wdowa po nim, Anna z Wernerów i kolejni członkowie rodziny. Górna kondygnacja budowli, z godnie $\mathrm{z}$ wolą fundatorki, służyła całej parafii jako kaplica przedpogrzebowa ${ }^{63}$.

Matylda i Edward Herbstowie mieszkali od 1896 r. w Sopocie, gdzie na kupionej pięć lat wcześniej parceli zbudowali wysmakowaną architektonicznie willę. Oboje włączyli się w szereg przedsięwzięć realizowanych $\mathrm{w}$ tym coraz bardziej popularnym kurorcie ${ }^{64}$. W sporządzonym 18 kwietnia $1901 \mathrm{r}$. i zachowanym do dziś akcie erekcyjnym kościoła Zbawiciela (Erloeser Kirche zu Zoppot; obecnie rzymskokatolicki kościół św. Jerzego) można przeczytać: „Dzwonnicę ufundował radca handlowy Edward Herbst z Łodzi”65. Z kolei Matylda ufundowała jedno z sześciu trójdzielnych okien w nawie głównej. Edward Herbst wspierał także finansowo szereg inwestycji miejskich w Sopocie. Między innymi odnowił i częściowo na nowo urządził wokół swej rezydencji istniejący do dzisiaj park oraz wybudował w nim palmiarnię.

Altruizm, potrzeba serca, protestancki światopogląd były zapewne najgłębszymi motywami tak szerokiego angażowania się Scheiblerów, Herbstów i Geyerów w działalność dobroczynną. Przeznaczali na nią niebagatelne środki

\footnotetext{
${ }^{61}$ Puś i Pytlas 1979, s. 172.

${ }^{62}$ Pytlas 1994, s. 335, Stefański 2006.

${ }^{63}$ Beschreibung der Scheiblerschen Begräbniskapelle 1909, s. 5.

${ }^{64}$ Spierski 2004, s. 2-3.

${ }^{65}$ Muzeum Dawnego Sopotu w Sopocie, sygn. 1901/84.
} 
finansowe, nieporównywalne z przekazywanymi przez innych ofiarodawców ${ }^{66}$. Pobieżny ich szacunek zamyka się sumą ponad $1 \mathrm{mln}$ rb (do $1914 \mathrm{r}$.), z czego blisko $25 \%$ stanowiły ofiary na budowę i wyposażenie łódzkich świątyń chrześcijańskich ${ }^{67}$. Duża część pozostałej kwoty zmaterializowała się w postaci instytucji, budynków, urządzeń, które służą łodzianom i mieszkańcom Sopotu do dziś.

Opisane wyżej przejawy życia religijnego prominentnych przedstawicieli środowiska łódzkich przemysłowców - protestantów, nie mieszczą się wśród wyróżnianych współcześnie trzech podstawowych wymiarów zaangażowania religijnego ${ }^{68}$. Niewątpliwie status społeczno-ekonomiczny, którym cieszył się krąg opisanych przemysłowców i ich rodzin, pozwalał na ponadprzeciętne (w wymiarze finansowym), angażowanie się w przedsięwzięcia o charakterze filantropijnym i dobroczynnym. Taka aktywność postrzegana była jako zgodna z protestanckim etosem pracy, świadczyła o pobożności.

\section{THE RELIGIOUS DIMENSION OF SOCIAL ACTIVISM AMONG PROTESTANT INDUSTRIALISTS IN THE 19TH-20TH-CENTURY ŁÓDŹ: THE SCHEIBLERS, THE HERBSTS, AND THE GREYERS}

\section{Summary}

The historical conditions which caused Łódź to develop as a metropolis with booming textile industry brought forth an elite where persons of Lutheran denomination accounted for $60 \%$ of its composition. Still, that most numerous Lutheran milieu in the Kingdom of Poland had all the hallmarks of a diaspora. The paper is thus concerned with the manifestations of religious life among the families of Łódź industrialists. The author underscores the significance of work, a virtue which was highly valued in that milieu being, after all, a fundamental quality in the Protestant doctrine. The reader is acquainted with the Evangelical culture of everyday life in the sacred and secular domains. Finally, the author advances conclusions about the correlation between the Protestant worldview and ethics and the demands of the nascent capitalism.

\footnotetext{
${ }^{66}$ Pytlas 1998a, s. 131.

${ }^{67}$ Pytlas 1994, s. 365, Stefański 1995, s. 108.

${ }^{68}$ Stark i Bainbridge 2000, s. 72-73.
} 


\section{Bibliografia}

Angerstein P.W. 1909, Andenken an die Jubelfeste in der St. Johannisgemeinde zu Lodz am 8. und 10. Oktober 1909, Lodz.

Badziak K., Chylak K., Łapa M. 2014, Łódź wielowyznaniowa. Dzieje wspólnot religijnych do 1914 r., Łódź.

Beschreibung der Scheiblerschen Begräbniskapelle auf dem evangelisch-lutherischen Kirchhoh in Lodz, 1890, Lodz.

Brandes D. 1993, Von den Zaren adoptiert. Die deutsche kolonisten und die Balkansiedler in Neurußland und Besarabien, München.

Czembor H. 1998, Dzieje parafii luterańskich w Łodzi do 1939 r., [w:] B. Milerski, K. Woźniak (red.), Przeszłość przyszłości. Z dziejów luteranizmu w Łodzi i regionie, Łódź, s. 45-82.

Dietrich J. 1934, 50 Jahre göttlicher Barmherzigkeit. Festschrift anläßlich des 50 jährigen Jubiläums der evang.-luth. St. Johannisgemeinde zu Lodz, Lodz.

Dziennik Łódzki 1884 136, 182, 225; 1885 64; 1886 3; 1887, 210.

Gastpary W. 1997, Historia protestantyzmu w Polsce od połowy XVIII wieku do pierwszej wojny światowej, Warszawa.

Geyer H.A. 2002, Z mojego życia. Wspomnienia z lat 1855-1915 / Aus meinem Leben/ Erinnerungen aus den Jahren 1855-1915, red. K.P. Woźniak, kom. językoznawczy J. Riecke, Łódź.

Głosy Kościelne w Sprawie Kościoła Ewangelicko-Augsburskiego 1885, nr 15.

Janczak J. 1982, Ludność Łodzi przemysłowej 1820-1914, Łódź.

Jubiläumsschrift der „Lodzer Zeitung” 1863-1913, 1913, Lodz.

Koffler L. 1979, Zur Geschichte der bürgerlichen Gesellschaft, Darmstadt.

Kopczyńska-Jaworska B. 1977, Obyczaje codzienne i świąteczne ewangelików łódzkich w ostatnich dwóch stuleciach, Zeszyty Naukowe Uniwersytetu Jagiellońskiego. Studia Religiologica 30, s. 115-127.

Kopczyńska-Jaworska B. 1999, Łódź i inne miasta, Łódź.

Kopczyńska-Jaworska B., Woźniak K. 2002, Łódzcy luteranie. Społeczność i jej organizacja, Łódź.

Kornacker R. 1998, Karl Scheibler der Vater von Lodz und Seine Stadt, [w:] B. Hoffmann (red.), Gerufen, vertrieben, zu Hause, Köln, s. 119-132.

Krajewska H. 2014, Protestanci w Lodzi 1815-1914. Między edukacją a ewangelizacją, Warszawa.

Krajewska H. 1996, Zur Geschichte des Lodzer Christlichen Wohltätigkeit-Vereins 1877-1914, [w:] J. Hensel (red.), Polen, Deutsche und Juden in Lodz 1820-1939. Eine schwierige Nachbarschaft, Osnabrück, s. 171-196.

Księga pamiątkowa 25-lecia pracy Pogotowia Ratunkowego w Łodzi, 1927, Łódź.

Markiewicz S. 1982, Protestantyzm, Warszawa.

Milerski B. 1998, Zamiast zakończenia: przeszłość przyszłości. Protestantyzm między utopią a praktyką społeczną, [w:] B. Milerski, K. Woźniak (red.), Przeszłość przyszłości. Z dziejów luteranizmu w Łodzi i regionie, Łódź, s. 231-246.

Mogilnicki T. 1930, Dwudziestopięciolecie szpitala Anny Marii w Łodzi: 1905-1930, Łódź.

Muzeum Dawnego Sopotu w Sopocie, sygn. 1901/84.

Pamiatnaja Kniżka Petrkovskoj Gubernii za 1887 god, 1888, Petrokov.

Pustuła Z. 1994, Karol Wilhelm Scheibler, [w:] Polski Słownik Biograficzny, 35, s. 426-428.

Puś W., Pytlas S. 1979, Dzieje Łódzkich Zakładów Przemysłu Bawełnianego im,. Obrońców Pokoju „Uniontex” (d. Zjednoczonych Zakładów K. Scheiblera i L. Grohmana) w latach 1827-1927, Warszawa-Łódź.

Pytlas S. 1994, Łódzka burżuazja przemysłowa w latach 1864-1914, Łódź.

Pytlas S. 1998a, Księży Młyn i okolice. Jego właściciele i ich zakłady, [w:] D. Berbelska (red.), Księży Młyn, Łódź, s. 15-41. 
Pytlas S. 1998b, Powstanie i działalność szpitala w latach 1902-1918, [w:] S. Pytlas, W. Sułat, T. Wierzbicki (red.), Szpital dla nerwowo i psychicznie chorych im. dra Józefa Babińskiego w Łodzi 1902-1987 (dawna „Kochanówka”), Łódź, s. 3-38.

Rynkowska A. 1948-1958, Geyer Ludwik, [w:] Polski Słownik Biograficzny 7, s. 414-415.

Rynkowska A. 1975, Przedsiębiorstwo Ludwika Geyera w latach 1828-1870, Centralne Muzeum Włókiennictwa, Łódź, s. 61-98.

Rzepkowski A. 2008, Ludność miasta Łodzi w latach 1918-1939, Łódź.

Schedler G. 1929, Eben-Ezer. Eine Jahrhundertgeschichte der evangelischen St. Trinitatis Gemeinde zu Lodz, Lodz.

Schmidt A., b.r.w., Die St. Trinitatiskirche. Evangelische Mutter-Gemeinde in Lodz, Mönchengladbach.

Sosnowska J. 2017, Opieka nad dziećmi w Łodzi w latach pierwszej wojny światowej, Łódź.

Spierski M. 2004, Sopockie pasje łódzkiego przemysłowca, Rocznik Sopocki.

Sprawozdanie z działalności Łódzkiego Chrześcijańskiego Towarzystwa Dobroczynności za r. 1913, 1913, Łódź.

Stark R., Bainbridge W.S. 2000, Teoria religii, Kraków.

Stefański K. 1995, Architektura sakralna Łodzi w okresie przemysłowego rozwoju miasta 1821-1914, Łódź.

Stefański K. 1996, Bazylika archikatedralna w Łodzi pw. św. Stanisława Kostki, Łódź.

Stefański K. 2006, Kaplica grobowa Karola Scheiblera w Łodzi. Perła architektury neogotyckiej, Łódź.

Stefański K. 2016, Scheiblerowie - wiara i edukacja, [w:] E.M. Bladowska (red.), O Scheiblerach jeszcze więcej, Łódź, s. 47-68.

Strzałkowski J. 2005, Kościół ewangelicko-augsburski w Łodzi, Łódź.

Supady J. 1977, Powstanie i rozwój ochronek, przytułków, sierocińców dla dzieci w Łodzi na przełomie XIX i XX w., Zdrowie Publiczne 78, s. 277-283.

Supady J. 1979, Powstanie i organizacja pierwszego szpitala dla dzieci w Łodzi w latach 1904-1914, Szpitalnictwo Polskie 29, s. 1924

Walaszczyk A. 2006, Łódź katolicka, Łódź.

Weber M. 1984, Szkice z socjologii religii, Warszawa.

Weber M. 1994, Etyka protestancka a duch kapitalizmu, Lublin.

Wiernicka V. 2015, Prawosławni w Łodzi, Łódź.

Woźniak K.P. 1998, Miastotwórcza rola łódzkich ewangelików w latach 1820-1939, [w:] B. Milerski, K. Woźniak (red.), Przeszłość przyszłości. Z dziejów luteranizmu w Łodzi i regionie, Łódź, s. 83-116.

Woźniak K.P. 2012, Burżuazja łódzka, polska, europejska w XIX wieku. Podobieństwa i różnice, [w:] M. Jakóbczyk, K. Kuropatwa-Pik, C. Pawlak (red.), Imperium rodziny Poznańskich. Przywrócone dziedzictwo czasu i miejsca, Łódź, s. 47-65.

Woźniak K.P. 2013, Niemieckie osadnictwo wiejskie między Prosną a Pilicą i Wisłą od lat 70. XVIII w. do 1866 r. Proces i jego interpretacje, Łódź.

Zuberbier A i in. 1988, Porównanie wyznań: rzymskokatolickiego, prawosławnego, ewangelicko-augsburskiego, ewangelicko-reformowanego, Warszawa. 